DOI: https://doi.org/10.47405/mjssh.v7i1.1219

\begin{tabular}{|c|c|}
\hline 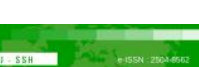 & Malaysian Journal of Social Sciences and Humanities (MJSSH) \\
\hline $\begin{array}{l}\text { Malaysian Journal of } \\
\text { socai sciences and }\end{array}$ & Volume 7, Issue 1, January 2022 \\
\hline (MJ-ssH) & e-ISSN : 2504-8562 \\
\hline & $\begin{array}{l}\text { Journal home page: } \\
\text { www.msocialsciences.com }\end{array}$ \\
\hline
\end{tabular}

\title{
Design and Technology in Malaysian Secondary Schools: A Perspective on Challenges
}

\author{
Gloria Ajit ${ }^{1}$, Terry Lucas ${ }^{1}$, Ringah Kanyan ${ }^{1}$ \\ ${ }^{1}$ Faculty of Applied and Creative Arts, Universiti Malaysia Sarawak (UNIMAS), Malaysia \\ Correspondence: Gloria Ajit (gloriaajitfrancis@gmail.com)
}

\begin{abstract}
Design and Technology (D\&T) is a relatively new curriculum in Malaysian secondary schools. The basic idea of a design-based curriculum is to facilitate deeper learning for learners to design and develop knowledge and application. However, knowing how design-based education is employed in schools is crucially essential. Therefore, this study aimed to obtain insights into the D\&T curriculum implementation from students and teachers' viewpoints. The study involved semi-structured interviews with four teachers and five secondary school students. Interviews were transcribed verbatim, while conclusions were drawn based on theme analysis. The findings indicated that students and teachers recognised the purpose and direction of the D\&T curriculum. Nevertheless, challenges exist in various aspects, as the subject is still in the early implementation stages. Challenges such as teachers' knowledge and skills, students' lack of understanding in abstract topics and insufficient facilities, equipment, and resources offer opportunities for researchers to explore relevant approaches to assist teachers and students in teaching and learning. Previous studies demonstrated the effectiveness of technology-assisted interventions to ease and overcome problems involving cost and time constraints. Thus, suitable technology-assisted strategies should be developed and utilised to facilitate the students' abstract details visualisation in technological application topics.
\end{abstract}

Keywords: Design and Technology, teacher's perception, student's perception, technologyassisted teaching strategy

\section{Introduction}

The 21st-century marks a rapid momentous shift in the global economy by moving towards the digital age and knowledge society. Changes in technological advancement and the job market's competitiveness have led to changes in the education system and provide younger generations with the required knowledge and expertise to thrive in the current global economy. Besides preparing students for the working world, higher order thinking skills are emphasised to comply with international education standards. Curriculum transformation from the Kurikulum Bersepadu Sekolah Menengah (KBSM) in 1989 to Kurikulum Standard Sekolah Menengah (KSSM) highlighted the enhancements of content, pedagogy, and assessment by underlining student's learning outcomes (Kementerian Pendidikan Malaysia, 2013). The curriculum transformation introduced D\&T subject, a Science, Technology, Engineering and Mathematics (STEM) domain that supports students' critical thinking skills in problem-solving as students create, assess, and redesign projects (Bahagian Pembangunan Kurikulum, 2019). 
The D\&T curriculum comprises the design and technological application basics through various approaches as problem-based learning (PBL) and project-based learning (PjBL) activities (Kementerian Pendidikan Malaysia, 2019a). The PBL is a curriculum model involving problem scenarios utilisation to encourage student involvement in the learning process (Fogarty, 1997). Students identify problems, find solutions, perform problem-solving operations, and evaluate problem-solving methods (Bahagian Pembangunan Kurikulum, 2014). Besides, PBL is an active and student-centred learning approach, where real and complex unstructured problems are utilised as a beginning point in the learning process (Tan, 2004).

Similarly, PjBL involves a dynamic project-based approach where students gain in-depth knowledge through active real-world problem exploration (Yao et al., 2019). Students in PjBL guided lessons learn to plan and chart their projects' progress. Students may need to make necessary improvements and adjustments during plan implementation to complete the project within the stipulated timeline. Both PBL and PjBL enhance student time management, critical and analytical thinking, innovation, and collaborative work that ensure the practical completion of problem-solving and projects.

The D\&T topics cover the introduction to D\&T, project management, design processes, ideas generation, and inventive problem-solving methods. The technological application comprises crosscurricular topics related to science and technology, art, agriculture, food, and fashion (Refer to Table 1). An example of science and technology related to the subject include electrical design, where performance standards require students to design and build electrical gadgets at the end of the lesson. Basic electricity knowledge, such as circuit types (parallel and series), electrical components, voltage, current, and resistance, is necessary to relate the electricity definition so that the gadget is designed and produced. Resultantly, a relatively long learning period is allocated to each technology application topic, approximately eight to ten hours, to enable PBL and PjBL. The curriculum implementation emphasises the outcome and systematic problem-solving process involving students thinking skills and collaborative learning.

Table 1: Content and learning standards (Kementerian Pendidikan Malaysia, 2019b)

\section{Content Standards}

\begin{tabular}{|c|c|c|c|}
\hline \multicolumn{2}{|c|}{ Content Standards } & Learning Standards & Learning Hours \\
\hline \multirow{5}{*}{ Basic of D\&T } & Introduction to D\&T & $\begin{array}{l}\text { Produces new objects from the basic } \\
\text { shape }\end{array}$ & 10 \\
\hline & Project management & $\begin{array}{l}\text { Plan a project management } \\
\text { paperwork }\end{array}$ & 6 \\
\hline & Design process & $\begin{array}{l}\text { Produce mock-ups from brief project } \\
\text { forms }\end{array}$ & 10 \\
\hline & Sketch & Create added value sketches & 24 \\
\hline & $\begin{array}{l}\text { Inventive problem- } \\
\text { solving }\end{array}$ & $\begin{array}{l}\text { Produce product development } \\
\text { sketches }\end{array}$ & 6 \\
\hline \multirow{9}{*}{$\begin{array}{l}\text { Technological } \\
\text { application }\end{array}$} & $\begin{array}{l}\text { Fertigation system } \\
\text { design }\end{array}$ & $\begin{array}{l}\text { Construct mock-ups of new } \\
\text { fertigation system structure }\end{array}$ & 10 \\
\hline & Fashion design & Fashion design & 10 \\
\hline & $\begin{array}{l}\text { Manufacturing } \\
\text { technology }\end{array}$ & Create 3D models and model packs & 10 \\
\hline & Mechanical design & $\begin{array}{l}\text { Construct a functional mechanical } \\
\text { gadget }\end{array}$ & 10 \\
\hline & Electrical design & $\begin{array}{l}\text { Design and construct an electrical } \\
\text { gadget }\end{array}$ & 10 \\
\hline & Electronic design & $\begin{array}{l}\text { Building electronic circuits of the } \\
\text { micro-processing controller }\end{array}$ & 10 \\
\hline & $\begin{array}{l}\text { Aquaponic system } \\
\text { design }\end{array}$ & $\begin{array}{l}\text { Builds aquaponic systems design } \\
\text { and documentation }\end{array}$ & 10 \\
\hline & Food design & Produce food and packaging design & 8 \\
\hline & Mechatronic & $\begin{array}{l}\text { Make modifications to the } \\
\text { mechatronic elements of the product }\end{array}$ & 14 \\
\hline
\end{tabular}




\begin{tabular}{llc} 
Product development & creatively & Product creation and documentation \\
$\begin{array}{l}\text { Design as a } \\
\text { marketing instrument }\end{array}$ & Create an advertising design & 44 \\
\hline
\end{tabular}

*Note: D\&T - Design and Technology

\section{Overview of the Current State of D\&T Education}

The D\&T curriculum implementation in Malaysia is based on the Dokumen Standard Kurikulum dan Pentaksiran (DSKP), a guide provided by the Bahagian Pembangunan Kurikulum (BPK), Ministry of Education (MOE) Malaysia. The DSKP comprises 21st-century teaching and learning pedagogical education strategies and emphasises students thinking skills through exposure to cross-curricular elements in the subject. The content organisation is structured and categorised as content and learning standards guiding the teaching and learning process.

Content standards are specific topics that cover cognitive aspects, skills, and values needed for students. Learning standards are criteria or metrics of measurable learning quality for each content level. In contrast, learning standards refer to general requirements indicating the performance level that students need to demonstrate to indicate that they have learned something. Learning standards cover cognitive, affective, and psychomotor domains, while the assessment is based on general learning standards guide to ensure fair and accurate assessment (Refer to Table 2).

Table 2: General learning standards guide (Kementerian Pendidikan Malaysia, 2017)

\begin{tabular}{cl}
\hline $\begin{array}{c}\text { Performance } \\
\text { Level }\end{array}$ & \multicolumn{1}{c}{ Descriptors } \\
\hline 1 & $\begin{array}{l}\text { Students are familiar with the basics and skills in the design, manufacture, and } \\
\text { construction of objects. } \\
\text { Students can explain the design process, problem-solving process, the role of } \\
\text { each part, and production of the product. }\end{array}$ \\
3 & $\begin{array}{l}\text { Students can apply their knowledge and skills to design and build goods. } \\
\text { Students can analyse ideas, materials, components, processes, and techniques to } \\
\text { develop a product. }\end{array}$ \\
5 & $\begin{array}{l}\text { Students can justify the knowledge and skills they acquired, produce } \\
\text { documentation, and present the product consistently. } \\
\text { Students can create designs and products independently, creatively, innovatively } \\
\text { and make use of their ideas. }\end{array}$ \\
\hline
\end{tabular}

Challenges remain in implementing the new subject at schools, although detailed DSKP and teaching manuals are given while teachers are trained. As D\&T was introduced in 2017, selected teachers, mainly from the Technical and Vocational Department (Cathrine \& Sabariah, 2019), were summoned to attend an introductory course covering the proposed pedagogy for efficient topics delivery and training at the initial KSSM implementation stage.

However, several teachers still lack confidence in delivery, specifically in technological applications, although resources and documentation standards have been set (Graves et al., 2016). Poor content knowledge harms the teaching process (Donna \& Hick, 2017; Gess-Newsome et al., 2019; Mammadov \& Çimen, 2019), making learning sessions ineffective and leads to poor classroom management (Olasehinde-Williams et al., 2018). Teachers' lack of time management skills has also resulted in PBL and PjBL lessons being carried out within a limited period (Zamri \& Nurfaradilla, 2020) and unsuccessful in achieving the lesson goals.

Thus, teachers require organisational support in resources and coaching (Graves et al., 2016; Plessis, 2016; Nanayakkara et al., 2018) such as teaching aids, continuous training, support from the Professional Learning Community (PLC) and suitable pedagogical approaches practically (Khanlari, 2016; Shuilleabhain \& Seery, 2018) to increase self-confidence in the new curriculum implementation. 
Furthermore, support for teachers in implementing a new curriculum would assist teachers and students (Roblin et al., 2018) as practical approach results in students' achievement (Ríordain et al., 2017; Fischer et al., 2018).

Studies have demonstrated that pedagogical and content knowledge factors do not necessarily affect students' achievement, as achievement is also based on prior experience (Keller et al., 2017; Fischer et al., 2018; Achmetli et al., 2019). Students with prior knowledge know the situation learned and can quickly understand the lesson as they can visualise and explain the subject posed and display a positive attitude (Li, 2019). Problem-solving based on actual scenarios improves student's procedural and conceptual knowledge per the mental picture of their experience (Khun-Inkeeree et al., 2017).

Knowing how schools employ design-based education is important as D\&T is a new curriculum in Malaysian high schools. Hence, this research aimed to gather feedback from students and teachers' perspectives on this curriculum implementation. Besides, this study attempted to identify the challenges they faced during the process. This study is expected to enable the respective party to prepare and provide practical suggestions for improvement. This study addresses two research questions:

i. What is the perception of teachers and students about the D\&T subject?

ii. What are the challenges of learning the D\&T subject?

\section{Past Studies on D\&T Subjects in Malaysia}

Studies on D\&T subjects in Malaysia from 2016 onwards mostly revolved around teachers' knowledge and interventions in learning and teaching. The extent of the achieved subject goal depends on teachers and students. Cathrine and Sabariah (2019) explored teacher's Content Pedagogy Knowledge (CPK) through interviews, observations, and document analysis following the issue of D\&T teachers not being well-trained to teach the subject. Their results indicated that teachers' CPK had not reached a satisfactory level. In the study, teachers tend to use the traditional lectures approach due to time and resource constraints, although they are aware of the suitable pedagogical approach proposed in DSKP.

Thus, the significant awareness of the teachers' CPK in motivating students to learn has led to efforts to develop the technological pedagogical content knowledge (TPACK) framework through Nominal Group Techniques (Fazidah et al., 2019). Both studies from Cathrine and Sabariah (2019), and Fazidah et al. (2019) highlighted the significance of CPK and TPACK among teachers. Well-equipped and knowledgeable teachers will motivate students by diversifying approaches, methods, and assessments throughout teaching and learning sessions.

An experimental study by Nur Syafiqah and Nurul Nazirah (2018) on secondary school students found that visualisation aids, such as computer graphics, enabled students to understand concepts through images shown. Students' interest and thinking skills will indirectly increase when students can easily understand a specific subject. Constraints in teachers' technological content knowledge and limited time and resources can be addressed by planning and using appropriate visual aids representing abstract and complex subjects. The successful visualisation software utilisation helps students gain in-depth understanding (Stieff, 2019) and increase student engagement and active involvement (Yang \& Liu, 2019).

In addition to pedagogical and technological knowledge factors, Zamri and Nurfaradilla (2020) observed the need for additional modules to support teaching due to constraints in teachers' knowledge, use of time, and teaching aids availability. Their survey showed that time allocation for theoretical topics and technology application affected the subject goals achievement. Utilising appropriate and cost-effective teacher-guided modules that integrate active learning teaching strategy is necessary to promote teaching and discourage teachers from returning to traditional teaching.

Additional two interventions include using mnemonic (Umi Fairus \& Fazlinda, 2018) and singing (Norhasyimah et al., 2018) for facilitating students' understanding. The existing technological gap has 
led students to consume more prolonged time to understand, master and apply the new knowledge gained. Resultantly, students have been able to develop their memory and comprehension of the learned topics. Nonetheless, both approaches are only acceptable for primary schools students. Therefore, this study addresses the research questions discussed earlier.

\section{Methodology}

The research aimed to explore in-depth perceptions of teachers and students regarding the D\&T teaching and learning process in secondary schools. The qualitative method was chosen to obtain a deep understanding of this issue. Qualitative research enables researchers to investigate the study indepth through participant response in real-life situations (Creswell \& Creswell, 2018).

\section{Participants}

The researchers in this study were interested in teachers and students' perspectives, understanding, and experience on introducing D\&T subjects in schools. Hence, the study participants comprised four Malaysian secondary school teachers and five secondary school students. The teachers' professional experience in teaching D\&T ranged from two to three years since the new curriculum implementation. All four female teachers were certified and trained by the Sarawak (three teachers) and Sabah State Education Department (one teacher) to teach D\&T. Five students were also approached for interviews at the end of the second semester in 2019. Three female and a male student, aged 15, studied in the same rural school, while another female student, aged 14, studied in an urban school in Sarawak.

\section{Data Collection and Analysis}

The research data were collected through semi-structured interview protocol instruments to explore the students and teachers' retrospection on the D\&T subjects' implementation. A purposive sampling approach was utilised in participant selection and determining to comprise teachers and D\&T students. Thus, the participant's perceptions related to the study purpose can be explored. In the initial stages of the research, participants were queried on their willingness to be interviewed. The study purpose and nature were clarified to the participants before they agreed to participate. The student participants achieved data saturation after interviewing five informants, while teacher participants attained data saturation after interviewing four informants. The participants were also informed that their private details would be kept confidential, and only the researchers would have access to it. The teachers and students' names were replaced by codes (e.g., T1, T2, T3, T4, S1, S2, S3, S4, S5) to maintain confidentiality.

The interview data analysis was undertaken through interview transcription, beginning with the first participant and findings, as Silverman (2013) suggested. Data from the interview transcripts were analysed using constant comparative methods to form themes (Merriam \& Tisdell, 2016). The findings of the subsequent interview were transcribed into word form. The careful interpretation enabled the researchers to spot recurring themes in the interview easily. Interview transcripts management produced the desired findings (Creswell \& Creswell, 2018). Five steps were taken to transcribe the interview data, as suggested by Yin (2016):

1. The researchers organised the data by reading it repeatedly to identify relevant information related to the study purpose.

2. A code was provided to the statement found by the participant. The right code would ease researchers in retrieving the original data and cross-referencing the interview information.

3. The categories of codes that have been set to associate those categories were identified.

4. A category theme was created and related to the research question.

5. The researchers utilised the theme formed to facilitate the process of writing a study report. 


\section{Findings and Discussion}

The researchers present the study findings from the qualitative data analysis in the upcoming section. The findings include comprehensive responses to the research questions on how the participants explained distinct viewpoints based on their D\&T education experience.

\section{What are the Perceptions of Teachers and Students about D\&T Subjects?}

\section{Finding 1: Involving students in every learning experience phase engages them on a deeper level of thinking skills.}

The teacher participants interviewed asserted that the D\&T curriculum is essential in producing students with higher order thinking skills and the capability of using the knowledge gained to resolve problems creatively and innovatively. One of the participants stressed the following response.

".... Skills of sketching from own ideas, solving problems, producing products" (T1)

Interviewed teacher participants believed that students' ability to sketch and visualise their ideas in problem-solving activity is higher order thinking skills due to their capability of transferring mental images in a form that can be pointed out and explained to their group members (T1, T4). Remarkably, the teacher participant observed that students' ability to visualise their ideas further enhances collaborative activities in a student-centred lesson. Additionally, interaction and communication between students through planning, goal setting, ideas, and group management solve related issues (T2, T3).

Conversely, although student participants agreed that this subject should be studied as a requirement in the prescribed curriculum, they also believe that thinking skills are part of an essential D\&T curriculum aspect. The student participants highlighted the following phrase.

$$
\text { ".... train higher-order thinking skills." (S3, S4, S5) }
$$

Student participants observed that the curriculum implementation is beneficial for developing higher order thinking skills. D\&T pedagogy that involves PBL and PjBL assist students to (i) identify problems, (ii) find solutions, (iii) perform problem-solving operations, (iv) generate ideas, (iv) plan to build objects as a solution to the problem, and (v) evaluate problem-solving methods utilised are beyond just knowing and understanding. PBL and PjBL inquiry can be effective learning means at any level because it is student-centred and encourages the development of practical and higher order thinking skills. Active, student-centred learning approach frequently enhances students' in-depth thinking skills in a real and complex unstructured problem as a starting point of the learning process (Tan, 2004). The student participants highlighted that:

".... master the topic and be able to apply knowledge through sketching of product design and product development" (S3, S4, S5)

Additionally, the student participants pointed out that learning D\&T allows them to apply the theories and facts gained to the problem-solving process and project-based approach during the lesson. Students apply information taught in the technology application topics by producing a problem-solving plan and generating ideas through sketches, mock-ups, or prototypes. Active student engagement in studentcentred learning allows students to think critically and creatively when faced with situations to be solved and convey the idea to other group members through collaboration.

\section{Finding 2: Student-centred learning supports creativity and innovative thinking.}

One teacher participant observed the creativity and innovation aspects of this curriculum as: 
".... visionary, creative, exposed to technology, innovative, curious" (T3)

The teacher participant agreed that student-centred learning could highlight student creativity, referring to the cognitive process of generating, developing, and modifying ideas according to problem-solving needs (Hyndman \& Mahony, 2018). Students no longer act as passive listeners receiving the knowledge taught but are actively involved in learning activities. The planning, sketching, testing, and reflection taking place in PBL encourage communication and planned innovations.

Student participant mentioned that their creative thinking is nurtured through the D\&T curriculum (S2). Student participants can conduct the problem-solving process by generating ideas and creating the product by recognising the concept articulated in the technological application topic (S3, S4, and S5). Besides, the planning and the problem-solving process involves discussion and new ideas formation that can reflect the students' creativity and innovation. The student participants understood the need for creativity in ideas generation to solve design-related problems for technology application topics. Responses from the interview showed that teachers and students are aware of the D\&T curriculum goals and direction, which is to apply cross-curricular knowledge and skills appropriate to 21 st-century learning.

As learning shifts towards student-centred approaches, the teachers' role has also transformed. School education has become more project-oriented and research-oriented but less teacher-oriented, implying that studying new content is strongly linked to learning from real-life scenarios and investigations. Therefore, the teachers' role enables students to improve their thinking practices using thinking tools (mind maps, inquiry) and promote their active participation in the learning process (Bahagian Pembangunan Kurikulum, 2014).

\section{What are the Challenges of Studying D\&T Subjects?}

\section{Challenge 1: Teachers lack prerequisite knowledge on the D\&T curriculum.}

The teacher's knowledge dimension proved that teachers still face restrictions in content knowledge. Due to poor content knowledge, the teacher participant demonstrated difficulty in presenting the five technology applications topics: fertigation, electrical, electronic, mechanical, and mechatronics system design. One of the teachers confessed that:

".... I do not know the fertigation system and rely entirely on textbooks. So, the mock-up that students do is not varied because it follows the example in the textbook." (T1)

"... I am not skilled in programming using Arduino. The number of Arduino sets is only five while the number of students is almost 40. Finally, I just teach the theory and show the Arduino that is already installed." (T1)

Limited knowledge of technology application topics and managing project-based activities has led the teacher participants to rely on textbooks entirely. Limited knowledge and training also restricted teachers from varying delivery methods (Aliusta \& Özer, 2017). This situation has led teachers to continue using teacher-centred teaching that involves listening to explanations, reading textbooks, and answering practical questions. Inadequate subject knowledge also contributed to less confidence in the teachers' delivery (Nolan \& Molla, 2017) and indirectly impacted the students' knowledge acquisition (Mammadov \& Çimen, 2019). Teachers' content knowledge is essential (Iserbyt et al., 2017; GessNewsome et al., 2019) so that content delivery can be effectively asserted to ensure that students benefit from knowledge acquisition.

As curriculum changes are necessary to adapt student's knowledge and skills for global future needs (Wang, 2019), the new curricula implementation is observed as facing various challenges, such as limited physical and human resources and vague implementation guidelines (Samson \& Charles, 2018; Nurulrabihah et al., 2020). Although initiatives to provide human resource needs training has been 
taken, the training conducted in a short period constraints the understanding of the new curriculum (Samson \& Charles, 2018). The teachers' support systems, such as in the PLC programme conducted in schools, need to be actively applied to improve the teachers' efficiency in designing, implementing and evaluating their teaching processes (Altan \& Ercan, 2016). In addition, appropriate strategies and approaches need to be explored to identify ways to support teachers in knowledge acquisition and delivery to avoid negative impacts on students.

\section{Challenge 2: Additional resources needed to achieve D\&T curriculum goals.}

The teacher knowledge participants were also challenged by limited resources and materials to carry out PBL and PjBL practical work. Among the confessions were:

".... The number of Arduino sets is only five while the number of students is almost 40. In the end, I just teach the theory and show the Arduino project that is already assembled." (T1)

"... not enough equipment for PjBL"

"... Teaching resources only depend on textbooks" (T3)

".... Inadequate tool and material" (T4)

Teacher participants pointed out that the quantity of teaching tools and material to assist learning is still limited due to insufficient resources to obtain all tools and material at once. However, the D\&T curriculum has already been implemented for three years. Purchasing teaching equipment is typically carried out in stages according to the amount allocated to the school each year. Insufficient teaching tools and materials will fail to meet the learning standards of related topics and need to be addressed (Limon, 2016; Lopes et al., 2019). Ample resources and teaching materials enable each content standard to be carried out efficiently (Hong \& Zimmer, 2016; Treeratanaporn, 2015) and enhance students' creativity (Hyndman \& Mahony, 2018).

Cost-effective, technology-assisted teaching strategies were utilised as an alternative to the existing teaching tools and equipment to overcome resources and equipment constraints. Technology-assisted teaching strategies, such as multimedia video instruction, facilitate the teaching and learning process, allowing students to be more independent in conducting self-directed learning (Jordan et al., 2016; Ahmad Zahir \& Ahmad Wali, 2020). The mobile application visualisation tool also assisted in mastering concepts and promoting learning activities (Alkhateeb \& Al-Duwairi, 2019; Gulatee \& Combes, 2018). Thus, appropriate technology-assisted teaching strategies might be considered to address the tools and materials limitations and support the teaching and learning process.

\section{Challenge 3: Transitioning to student-centred instruction is an ongoing process, one that takes years to refine.}

Students who are enthusiastically involved in the learning process will become more encouraged, more comfortable to impose questions, brainstorm ideas, and propose measures to solve the lesson's problem (Norlizawaty et al., 2018).
"... Students rely fully on teacher guidance. Students are less creative and eventually produce the same products as they did in Forms 1 and 2." (T1)
"... Students who are not visionary ... topics such as mechanical are new for students, teachers are less experienced in mechanical parts." (T3)

However, the teacher participants revealed that students who are still comfortable with teacher-centred teaching exist, suggesting reliance on teacher guidance and opinion during teaching and learning. 
Teacher participants considered the student's behaviour can be an obstacle to encourage critical thinking (Rubenstein et al., 2018).

Besides, constraints in teaching and learning time allocation, and the need to complete the given syllabus, challenges teachers to train students to be more creative in PBL activities (Harris \& Bruin, 2018; Rubenstein et al., 2018). Another challenge in student-centred learning, such as PBL, remains new to most students compared to conventional teaching and learning approaches (Norlizawaty et al., 2018). Students face the challenge of adapting to learning strategies and time management to complete a task. Furthermore, the teacher participants also discovered that a challenge in the curriculum implementation is low student motivation, specifically when moving to a new topic due to the preparation factors and student's prior knowledge.

\section{Challenge 4: The ability of students in using thinking skills to solve problems is not yet at a satisfactory level.}

Based on the student participants responses, all participants faced difficulty understanding technology application concepts. Since few topics are new to students, they could not see how the system operates and how concepts related to the system are applied. They cannot conduct problem-solving activities and the project construction related to the topic due to students' failure to visualise the entire concept and system. Poor understanding has hindered students from progressing to higher cognitive taxonomy levels, such as the concepts applied to solve design problems.

The technology application topics, such as fertigation, aquaponics, or manufacturing, require an understanding of the basic science and technology concepts. Some topics incorporate 21 st-century learning technologies and are a new student experience. Therefore, visualisation tools are also crucial for students to understand, primarily when the essential tools and materials are difficult to obtain and shown to students. Besides, visualisation through simulation is an approach that can contribute to students' understanding (Widiyatmoko, 2018). Simulation as a visualisation method allows students to gain procedural knowledge of complex concepts (Falloon, 2019). A student participant emphasised that:

".... need memorisation and memory skills to answer the assessment" (S2)

In addition, a low understanding level has led student participants to believe that they cannot memorise well. Students are still stuck with the memorisation idea and think that excelling in memorising will assist in mastering the subject. The students believe in the necessity to memorise to answer exam questions correctly for few topics, such as mechatronics, mechanicals, and electronic programming. Nonetheless, they failed to realise that knowledge does not rely on memorisation alone.

Without understanding the main concepts, memorising will only lead to misconceptions among students (Wiji \& Mulyani, 2018; Dai et al., 2019). Consequently, a lack of understanding will continue to occur due to the lack of in-depth comprehension. In reality, students need solid conceptual knowledge to relate and reason (Hattie \& Donoghue, 2016; Dai et al., 2019). Nonetheless, student knowledge can be enhanced through various strategies such as active learning (McConnell et al., 2018), collaboration, and scaffolding (Haruehansawasin \& Kiattikomol, 2018). Active learning involving communicating, making observations, and reflecting enhances understanding and promotes retention of knowledge.

The student participants named electrical design (S1, S2, S3, S4), mechatronics (S2), product development technology (S2), aquaponics (S4) and mechanical design (S1) when asked about topics challenging to understand. The difficulties faced may be due to the lack of understanding and planning through a brief project and product development process. Spatial visualisation skills are also a critical cognitive factor in student achievement (Budinoff \& McMains, 2018; Sorby \& Panther, 2020). Mastering a topic becomes tricky when students are unable to concretise the abstract information learned. Resultantly, they are unable to make connections to apply the facts learned. 
In short, teaching that adopts higher order thinking skills faces challenges. Memorisation and passive learning become commonplace in classes where students are familiar with teacher-based learning and exam-driven. Therefore, the teacher's role is critical in changing classroom practices through the use of student-oriented pedagogy. The challenges faced by teachers and students from the study interviews indicated the need for teaching aids to facilitate teachers in teaching and learning. Teaching aids in the form of teacher guidance modules contain clear implementation instructions based on learning standards (Siti Arfah et al., 2019; Zamri \& Nurfaradilla, 2020). Since most technology application topics are challenging to understand and visualise, appropriate technology-assisted teaching strategies are essential to support student learning leading to high-level thinking skills (Chinedu et al., 2015; Allcoat \& Mühlenen, 2018; Nurbekova et al., 2020).

\section{Challenge 5: Lack of emphasis on spatial visualisation capabilities in education.}

Another challenge the student participants encountered when studying D\&T is the inability to generate and represent ideas. The participants highlighted the following:

$$
\text { "... lack of drawing skills." (S1, S2) }
$$

Student participants were unsure of demonstrating their ideas well because of the subject's unfamiliarity with their current knowledge. The only visual information source on the topic was twodimensional (2D) images shown in textbook outlines.

Spatial visualisation capabilities allow individuals to imagine, understand, and make connections between objects in the same space to effectively implement student-centred learning (Patahuddin et al., 2018). Without the ability to visualise, learning is based on memorising facts to solve problems (Lonnemann et al., 2019). Visualisation skills are necessary for students as sketching in technology application topics requires students to describe and understand the rotation and transformation of the object that relates with each other, in several topics related with three-dimensional (3D) representations and models (Jaakkola \& Veermans, 2020). However, spatial visualisation skills can be enhanced through training and utilising appropriate learning models (Pujawan et al., 2020) and visualisation tools. A teacher participant particularly highlighting the following phrase:

$$
\text { "... poor student skills in isometrics sketching" (T4) }
$$

The teacher participant discovered that students with low spatial visualisation ability could not describe and explain their ideas well. Students are drawn to the topic separately and cannot relate to the topic across chapters. Teacher participant identified students with different backgrounds and learning styles, where students who quickly mastered the topics learned have high spatial visualisation skills (Hawes \& Ansari, 2020; Wetzel et al., 2020). Spatial visualisation skills are one of the main cognitive factors in student achievement (Budinoff \& McMains 2018; Margulieux, 2020; Sorby \& Panther, 2020). Nevertheless, conventional teaching methods frequently depend on utilising two-dimensional (2D) diagrams to lead students in the spatial cognition construction. The students' inadequate 3D and spatial capability limits the effectiveness of conventional teaching materials, whereas the student's existing spatial capacity also restricts the instructional effectiveness.

Spatial visualisation abilities should not be underestimated and ignored in the learning process as these abilities are related to student achievement and in-depth topic understanding (Kamran et al., 2019; Yao et al., 2019). Furthermore, utilising an actual 3D model representation resulted in better learning outcomes than utilising traditional three-view diagrams (Huang and Lin, 2016). Therefore, utilising appropriate visualisation technology is also crucial to facilitate a student's spatial visualisation skills (Margulieux, 2020). Emerging technology such as virtual and augmented reality (Leonard \& Fitzgerald, 2018; Saundarajan et al., 2020; Wahyu et al., 2020), interactive whiteboard (Wong et al., 2020) and other electronic media (Suparmi et al., 2020) allows students to attain more insight and comprehend greater information amount than the static images and information in textbooks. Students are inspired and able to grasp what the information reflects in a shorter period through viewing the information in the physical environment (Liu et al., 2020). 


\section{Challenge 6: Student motivation decreased due to low cognitive ability.}

Another challenge faced by the participants is the inability to engage in the D\&T lesson. The challenge has led to reduced interest and enthusiasm in the subjects. For instance, few student participants confessed that:

$$
\text { "... I am not talented in sketching." (S3, S5) }
$$

Students are usually required to pose their idea in a problem-solving exercise by generating their ideas. When the student was unable to present their ideas, they suspected their incompetence. Fernández and Ruiz-Gallardo (2017) claimed that visual literacy increase among students is limited if they are rarely exposed to various real-life images. Students less exposed to image variations from different ideas have trouble representing their thoughts. Transferring information from one type to another is challenging, as it requires higher order thinking skills but can be trained. Visual and teaching aids can help with motor skills in this situation (Cade et al., 2018). In addition, utilising visualisation tools in teaching and learning can trigger student's motivation (Jang, Yi, and Shin, 2016) and learning outcomes (Hediansah \& Surjono, 2019). Another limitation was highlighted:

$$
\text { "... product development takes a long time to complete." }
$$

Student participants lose interest in the subject due to poor understanding, ambiguous explanations, and a long learning session lasting up to ten hours. As teaching and learning function simultaneously, teachers are the central point and must lead their class accordingly. Active learning is vitally important in students' retention. Therefore, teachers are expected to adapt to changing student needs in a way that students appreciate the topics and objectives (Berger et al., 2018). The topic planning and delivery should also be undertaken by considering students, diversifying the teaching methods and using constructivist approaches (Alt, 2018). Student's critical thinking and creative skills are also improved through various classroom activities. Students who find lessons fascinating will be motivated to continue engaging in learning activities.

\section{Challenge 7: Collaborative activities are ineffective, especially with poor class control.}

A student participant found it challenging to perform in collaborative activities and mentioned the following:

$$
\text { ".... difficult to concentrate due to poor class control". (S2) }
$$

Student participant showed disappointment when members were uncooperative in group activities that ultimately disrupted their learning outcomes. The ineffectiveness of group activities often occurs when students have no social competence (Pang et al., 2018). Students may intend to complete the assignment anyhow without cooperating and interacting with the group members (Murray, 2017). Poor collaborative skills, such as the inability to accept opposing views, poor explanatory skills, and the failure to communicate, will result in unproductive learning. Resultantly, students also failed to communicate their ideas about problem-solving activities and their motivation to learn is affected.

Collaborative activities among students frequently encounter challenges and obstacles due to the lack of collaborative skills caused by students wanting to be free riders, group incompetence, and friendship factors (Le et al., 2018). A systematic literature review by Leeuwen and Janssen (2019) demonstrated that teachers' roles are vital in supporting collaborative activities between secondary school students through mentoring, guiding, and coaching from time to time. Teacher's classroom management involves using positive and negative reinforcements appropriate to the situation to give students a pleasant classroom environment impression (Ayebo \& Assuah, 2017; Bear et al., 2017; Berger et al., 2018). 


\section{Conclusion}

In summary, student and teacher participants have understood the purpose and direction of the D\&T curriculum. Teachers have been able to understand the potential of this subject by generating students with a creative mind and a capacity to innovate in actual life through training and exposure to the new curriculum. Students also acknowledge the significance of higher order thinking skills and creative thinking in student-centred lessons. However, limitations exist on various aspects, as the D\&T curriculum is in the early implementation stages. Facilities are limited, whereas teacher's knowledge and skills have not yet been well established. Thus, they require ongoing guidance, support, and training from the State Education Department and the teachers' community. Students have not shown a positive impact on the knowledge aspect as they possess a low visualisation and thinking skills. Poor class control that hinders collaborative activities also contributed to demotivation and loss of interest among students. Furthermore, the limited time allocation causes specific topics, such as technological applications, to be carried out hurriedly. The study practically provides significant findings for educational professionals in the preparation and utilisation of educational improvements. As the implementation of the D\&T curriculum is an ongoing process, the results of this study can be used to ensure that the purpose of this curriculum can be accomplished. Past studies have shown that technological interventions in various interactive technology-assisted teaching strategies help facilitate comprehension and resolving cost and time constraint problems. The technology-assisted teaching approach also provides teachers with additional teaching opportunities and time to evaluate learning activity progress. Emerging technologies, such as virtual and augmented reality, enable changes in realistic and productive learning. Hence, adopting technology-assisted teaching strategies in D\&T will help to facilitate teaching and learning. However, this qualitative study has limitations as it was undertaken on a small scale, with only four secondary school teachers and five secondary school students. Consequently, the findings cannot be generalised. Nevertheless, this research offers insights into D\&T education in secondary school practices.

\section{References}

Achmetli, K., Schukajlow, S., \& Rakoczy, K. (2019). Multiple solutions for real-world problems, experience of competence and students' procedural and conceptual knowledge. International Journal of Science and Mathematics Education, 17, 1605-1625.

Ahmad Zahir Wali, \& Ahmad Wali Popal. (2020). The emerging issues and impacts of technology in classroom learning. International Journal of Emerging Technologies in Learning, 15(15), 237245.

Alkhateeb, M. A., \& Al-Duwairi, A. M. (2019). The effect of using mobile applications (GeoGebra and Sketchpad) on the students' achievement. International Electronic Journal of Mathematics Education, 14(3), 523-533.

Allcoat, D., \& Mühlenen, A. von. (2018). Learning in virtual reality: Effects on performance, emotion and engagement. Research in Learning Technology, 26, 1-13.

Alt, D. (2018). Science teachers' conceptions of teaching and learning, ICT efficacy, ICT professional development and ICT practices enacted in their classrooms. Teaching and Teacher Education, 73, 141-150. https://doi.org/10.1016/j.tate.2018.03.020

Altan, E. B., \& Ercan, S. (2016). STEM education program for science teachers: Perception and competencies. Journal of Turkish Science Education, 13, 103-117. https://doi.org/10.12973/tused.10174a

Ayebo, A., \& Assuah, C. (2017). Exploring teachers' knowledge of classroom management and control. Malaysian Journal of Learning and Instruction, 14(1), 169-185. https://doi.org/10.32890/mjli2017.14.1.7

Bahagian Pembangunan Kurikulum. (2014). Kemahiran Berfikir Aras Tinggi: Aplikasi di Sekolah. Kementerian Pendidikan Malaysia.

Bahagian Pembangunan Kurikulum. (2019). Kurikulum Standard Sekolah Menengah (KSSM) Panduan Pelaksanaan Kurikulum Reka Bentuk Dan Teknologi (RBT). In Kementerian Pendidikan Malaysia. Unit Reka Bentuk dan Teknologi, Sektor Pendidikan Teknik dan Vokasional. http://bpk.moe.gov.my 
Bear, G. G., Yang, C., Mantz, L. S., \& Harris, A. B. (2017). School-wide practices associated with school climate in elementary, middle, and high schools. Teaching and Teacher Education, 63, 372-383. https://doi.org/10.1016/j.tate.2017.01.012

Berger, J., Girardet, C., Vaudroz, C., \& Crahay, M. (2018). Teaching experience, teachers' beliefs, and self-reported classroom management practices: A coherent network. SAGE Open, 1-12. https://doi.org/10.1177/2158244017754119

Budinoff, H., \& McMains, S. (2018). Relationships between spatial visualization ability and student outcomes in a 3D modeling course. Engineering Design Graphics Journal, 82(2), 17-23.

Cade, A., Sherson, M., Holt, K., Dobson, G., Pritchard, K., Haavik, H., Recall, M., \& Skills, M. (2018). Differences in learning retention when teaching a manual motor skill with a visual vs written instructional aide. Journal of Chiropractic Education, 32(2), 107-114. https://doi.org/10.7899/JCE-17-19

Cathrine Masingan, \& Sabariah Sharif. (2019). Pengetahuan pedagogi kandungan (PPK) guru bukan pengkhususan Reka Bentuk dan Teknologi (RBT) di sekolah menengah. Malaysian Journal of Social Sciences and Humanities, 4(6), 64-71. https://doi.org/2504-8562

Chinedu, C. C., Kamin, Y., \& Olabiyi, O. S. (2015). Strategies for improving higher order thinking skills in teaching and learning of Design and Technology education. Journal of Technical Education and Training, 7(2), 35-43.

Creswell, J. W., \& Creswell, J. D. (2018). Research design: Qualitative, quantitative and mixed methods approaches. In Thousand Oaks California (5th Ed.). SAGE Publications.

Dai, R., Fritchman, J. C., Liu, Q., Xiao, Y., Yu, H., \& Bao, L. (2019). Assessment of student understanding on light interference. Physical Review Physics Education Research, 15(2), 20134. https://doi.org/10.1103/PhysRevPhysEducRes.15.020134

Donna, J. D., \& Hick, S. R. (2017). Developing elementary preservice teacher subject matter knowledge through the use of educative science curriculum materials. Journal of Science Teacher Education, 28(1), 92-110. https://doi.org/10.1080/1046560X.2017.1279510

Falloon, G. (2019). Using simulations to teach young students science concepts: An experiential learning theoretical analysis. Computers \& Education, 135, 138-159. https://doi.org/10.1016/j.compedu.2019.03.001

Fazidah Naziri, Mohamad Sattar Rasul, \& Haryanti Mohd Affandi. (2019). Nominal Group Technique application on TPACK element requirements for Design and Technology teachers in Malaysia. International Journal of Academic Research in Business and Social Sciences, 9(4), 8-15. https://doi.org/10.6007/ijarbss/v9-i4/5810

Fernández, B. G., \& Ruiz-Gallardo, J. R. (2017). Visual literacy in primary Science: Exploring anatomy cross-section production skills. Journal of Science Education and Technology, 26, 161-174. https://doi.org/10.1007/s10956-016-9662-0

Fischer, C., Fishman, B., Dede, C., Eisenkraft, A., Frumin, K., Foster, B., Lawrenz, F., Levy, A. J., \& Mccoy, A. (2018). Investigating relationships between school context, teacher professional development, teaching practices, and student achievement in response to a nationwide science reform. Teaching and Teacher Education, 72, 107-121. https://doi.org/10.1016/j.tate.2018.02.011

Fogarty, R. (1997). Problem-based learning and other curriculum models for the multiple intelligences classroom. SkyLight Training and Publishing, Inc.

Gess-Newsome, J., Taylor, J. A., Carlson, J., Gardner, A. L., Wilson, C. D., \& Stuhlsatz, M. A. M. M. (2019). Teacher pedagogical content knowledge, practice, and student achievement. International Journal of Science Education, 41(7), 944-963. https://doi.org/10.1080/09500693.2016.1265158

Graves, L. A., Hughes, H., \& Balgopal, M. M. (2016). Teaching STEM through Horticulture: Implementing an edible plant curriculum at a STEM-centric elementary school. Journal of Agricultural Education, 57(3), 192-207. https://doi.org/10.5032/jae.2016.03192

Gulatee, Y., \& Combes, B. (2018). Owning ICT: Student use and ownership of technology. Walailak Journal of Science and Technology, 15(1), 81-94. https://doi.org/10.48048/wjst.2018.2868

Harris, A., \& Bruin, L. R. De. (2018). Secondary school creativity, teacher practice and STEAM education: An international study. Journal of Educational Change, 19(2), 153-179. https://doi.org/10.1007/s10833-017-9311-2 
Haruehansawasin, S., \& Kiattikomol, P. (2018). Scaffolding in problem-based learning for lowachieving learners. The Journal of Educational Research, 111(3), 363-370. https://doi.org/10.1080/00220671.2017.1287045

Hattie, J. A. C., \& Donoghue, G. M. (2016). Learning strategies: A synthesis and conceptual model. Npj Science of Learning, 1(1), 1-13. https://doi.org/10.1038/npjscilearn.2016.13

Hawes, Z., \& Ansari, D. (2020). What explains the relationship between spatial and mathematical skills? A review of evidence from brain and behavior. Psychonomic Bulletin and Review, 1-18. https://doi.org/10.3758/s13423-019-01694-7

Hediansah, D., \& Surjono, H. D. (2019). Building motivation and improving learning outcomes with android-based physics books: Education 4.0. Anatolian Journal of Education, 4(2), 1-10. https://doi.org/10.29333/aje.2019.421a

Hong, K., \& Zimmer, R. (2016). Does investing in school capital infrastructure improve student achievement? Economics of Education Review, 53, 143-158. https://doi.org/10.1016/j.econedurev.2016.05.007

Huang, T.-C., \& Lin, C.-Y. (2016). From 3D modeling to 3D printing: Development of a differentiated spatial ability teaching model. Telematics and Informatics. https://doi.org/10.1016/j.tele.2016.10.005

Hyndman, B., \& Mahony, L. (2018). Developing creativity through outdoor physical activities: A qualitative exploration of contrasting school equipment provisions. Journal of Adventure $\begin{array}{llll}\text { Education } \quad \text { Ond } & \text { Learning, }\end{array}$ https://doi.org/10.1080/14729679.2018.1436078

Jaakkola, T., \& Veermans, K. (2020). Learning electric circuit principles in a simulation environment with a single representation versus "concreteness fading" through multiple representations. $\begin{array}{llll}\text { Computers and } & \text { Education, 2018), }\end{array}$ https://doi.org/10.1016/j.compedu.2020.103811

Jang, D.-H., Yi, P., \& Shin, I.-S. (2016). Examining the effectiveness of digital textbook use on students' learning outcomes in South Korea: A meta-analysis. Asia-Pacific Education Researcher, 25(1), 57-68. https://doi.org/10.1007/s40299-015-0232-7

Jemaah Nazir, \& Kementerian Pendidikan Malaysia. (2019). Panduan Pengurusan Mata Pelajaran Reka Bentuk dan Teknologi (Kementerian Pendidikan Malaysia (Ed.); Pertama). Jemaah Nazir, KPM.

Jordan, J. T., Box, M. C., Eguren, K. E., Parker, T. A., Saraldi-Gallardo, V. M., Wolfe, M. I., \& Gallardo-Williams, M. T. (2016). Effectiveness of student-generated video as a teaching tool for an instrumental technique in the organic chemistry laboratory. Journal of Chemical Education, 93, 141-145. https://doi.org/10.1021/acs.jchemed.5b00354

Kamran, M., Munir, N., \& Wattoo, R. M. (2019). A comparative exploration of the effect of differentiated teaching method vs. traditional teaching method on students' learning at 'A' level. Global Social Sciences Review, 4(1), 61-66. https://doi.org/10.31703/gssr.2019(iv-i).08

Keller, M. M., Neumann, K., \& Fischer, H. E. (2017). The impact of Physics teachers' pedagogical content knowledge and motivation on students' achievement and interest. Journal of Research in Science Teaching, 54(5), 586-614. https://doi.org/10.1002/tea.21378

Kementerian Pendidikan Malaysia. (2012). Laporan Awal Pelan Pembangunan Pendidikan Malaysia 2013-2025. In Kementerian Pendidikan Malaysia. Kementerian Pendidikan Malaysia. https://doi.org/10.1016/j.tate.2010.08.007

Kementerian Pendidikan Malaysia. (2017). Kurikulum Standard Sekolah Menengah Reka Bentuk dan Teknologi: Dokumen Standard Kurikulum dan Pentaksiran Tingkatan 3. Bahagian Pembangunan Kurikulum.

Kementerian Pendidikan Malaysia. (2019). Panduan Pengurusan Mata Pelajaran Reka Bentuk dan Teknologi Sekolah Rendah dan Sekolah Menengah (Edisi Pert). Jemaah Nazir.

Khanlari, A. (2016). Teachers' perceptions of the benefits and the challenges of integrating educational robots into primary/elementary curricula. European Journal of Engineering Education, 41(3), 320-330. https://doi.org/10.1080/03043797.2015.1056106

Khun-Inkeeree, H., Omar-Fauzee, M. S., \& Othman, M. K. H. (2017). The effect of students confidence level toward Mathematics performance among Southern Thailand primary school children. International Journal of Academic Research in Progressive Education and Development, 6(2), 20-34. https://doi.org/10.6007/IJARPED/v6-i2/2934 
Le, H., Janssen, J., \& Wubbels, T. (2018). Collaborative learning practices: Teacher and student perceived obstacles to effective student collaboration. Cambridge Journal of Education, 48(1), 103-122. https://doi.org/10.1080/0305764X.2016.1259389

Leeuwen, A. Van, \& Janssen, J. (2019). A systematic review of teacher guidance during collaborative learning in primary and secondary education. Educational Research Review, 27, 71-89. https://doi.org/10.1016/j.edurev.2019.02.001

Leonard, S. N., \& Fitzgerald, R. N. (2018). Holographic learning: A mixed reality trial of Microsoft Hololens in an Australian secondary school. Research in Learning Technology, 26(1063519), 1-12. https://doi.org/10.25304/rlt.v26.2160

Li, L. (2019). Effect of prior knowledge on attitudes, behavior, and learning performance in video lecture viewing. International Journal of Human-Computer Interaction, 35(4-5), 415-426. https://doi.org/10.1080/10447318.2018.1543086

Limon, M. R. (2016). The effect of the adequacy of school facilities on students' performance and achievement in technology and livelihood education. International Journal of Academic Research in Progressive Education and Development, 5(1), 45-58. https://doi.org/10.6007/IJARPED/v5-i1/2060

Liu, Z.-J., Levina, V., \& Frolova, Y. (2020). Information visualization in the educational process: Current trends. International Journal of Emerging Technologies in Learning, 15(13), 49-62.

Lonnemann, J., Müller, C., Büttner, G., \& Hasselhorn, M. (2019). The influence of visual-spatial skills on the association between processing of nonsymbolic numerical magnitude and number word sequence skills. Journal of Experimental Child Psychology, 178, 184-197. https://doi.org/10.1016/j.jecp.2018.09.018

Lopes, D., Moreira, I. X., Ribeiro, M. da C., Santos, A. G. Dos, \& Costa, A. da. (2019). Impacts of environment and school facilities on student learning achievement in secondary school. Journal of Innovative Studies on Character and Education, 3(2), 256-269.

Mammadov, R., \& Çimen, I. (2019). Optimizing teacher quality based on student performance: A data envelopment analysis on PISA and TALIS. International Journal of Instruction, 12(4), 767788. https://doi.org/10.29333/iji.2019.12449a

Margulieux, L. E. (2020). Spatial encoding strategy theory: The relationship between spatial skill and STEM achievement. ACM Inroads, 11(1), 65-75. https://doi.org/10.1145/3381891

McConnell, D. A., Chapman, L., Czajka, C. D., Jones, J. P., Ryker, K. D., \& Wiggen, J. (2018). Instructional Utility and Learning Efficacy of Common Active Learning Strategies Strategies. Journal of Geoscience Education, 65(4), 604-625. https://doi.org/10.5408/17-249.1

Merriam, S. B., \& Tisdell, E. J. (2016). Qualitative research: A guide to design and implementation (4th Ed.). Jossey-Bass.

Murray, J. W. (2017). I hate/don't hate/still hate group projects! A tripartite ethical framework for enhancing student collaboration. Cogent Education, 2(1), 1377507. https://doi.org/10.1080/2331186X.2017.1377507

Nanayakkara, J., Margerison, C., \& Worsley, A. (2018). Teachers' perspectives of a new food literacy curriculum in Australia. Health Education, 118(1), 48-61. https://doi.org/10.1108/HE-05-20170024

Nolan, A., \& Molla, T. (2017). Teacher confidence and professional capital. Teaching and Teacher Education, 62, 10-18. https://doi.org/10.1016/j.tate.2016.11.004

Norhasyimah Hamzah, Roziyati Omar, Arihasnida Ariffin, Siti Nur Kamariah Rubani, \& Tamil Selvan Subramaniam. (2018). Penggunaan kaedah nyanyian dalam mata pelajaran Reka Bentuk dan Teknologi. Online Journal for TVET Practioners. http://active.uthm.edu.my/ejournal/volume/2018/26.pdf

Norlizawaty Baharin, Nurzatulshima Kamarudin, \& Umi Kalthom Abdul Manaf. (2018). Integrating STEM education approach in enhancing higher order thinking skills. International Journal of Academic Research in Business and Social Sciences, 8(7), 810-821. https://doi.org/10.6007/IJARBSS/v8-i7/4421

Nur Syafiqah Isa, \& Nurul Nazirah Mohd Imam Ma'arof. (2018). Keberkesanan penggunaan grafik berkomputer sebagai alat bahan bantu mengajar dalam kalangan pelajar Reka Bentuk dan Teknologi. Sains Humanika, 3(3), 81-87. https://doi.org/10.11113/sh.v10n3-3.1519 
Nurbekova, Z., Grinshkun, V., Aimicheva, G., Nurbekov, B., \& Tuenbaeva, K. (2020). Project-based learning approach for teaching mobile application development using visualization technology. International Journal of Emerging Technologies in Learning, 15(8), 130-143.

Nurulrabihah Mat Nor, Siti Hajar Halili, \& Saedah Siraj. (2020). Analisis faktor kekangan pembelajaran berasaskan reka bentuk dalam kalangan guru berdasarkan Fuzzy Delphi method. Jurnal Kurikulum \& Pengajaran Asia Pasifik, 8(1), 33-42.

Olasehinde-Williams, F., Yahaya, L., \& Owolabi, H. (2018). Teachers' knowledge indices as predictors of secondary school students' academic achievement in Kwara State, Nigeria. IAFOR Journal of Education, 6(1), 73-90. https://doi.org/10.22492/ije.6.1.05

Onurkan Aliusta, G., \& Özer, B. (2017). Student-centred learning (SCL): Roles changed? Teachers and Teaching: Theory and Practice, 23(4), 422-435. https://doi.org/10.1080/13540602.2016.1205014

Pang, C., Lau, J., Seah, C. P., Cheong, L., \& Low, A. (2018). Socially challenged collaborative learning of secondary school students in Singapore. Education Sciences, 8(1), 1-10. https://doi.org/10.3390/educsci8010024

Patahuddin, S., Logan, T., \& Ramful, A. (2018). Characteristics of spatial visualisation: Perspectives from area of composite shapes. Mathematics Education Research Group of Australasia, 623630.

Plessis, A. E. Du. (2016). Leading teachers through the storm: Looking beyond the numbers and turning the implications of out-of-field teaching practices into positive challenges. International Journal of Educational Research, 79, 42-51. https://doi.org/10.1016/j.ijer.2016.06.010

Pujawan, I. G. N., Suryawan, I. P. P., \& Prabawati, D. A. A. (2020). The effect of Van Hiele Learning Model on students' spatial abilities. International Journal of Instruction, 13(3), 461-474.

Ríordain, M. N., Paolucci, C., \& Dwyer, L. M. O. (2017). An examination of the professional development needs of out-of-field mathematics teachers. Teaching and Teacher Education, 64, 162-174. https://doi.org/10.1016/j.tate.2017.02.001

Roblin, N. P., Schunn, C., \& McKenney, S. (2018). What are critical features of Science curriculum materials that impact student and teacher outcomes? Science Education, 102(2), 260-282. https://doi.org/10.1002/sce.21328.This

Rubenstein, L. D., Ridgley, L. M., Callan, G. L., Karami, S., \& Ehlinger, J. (2018). How teachers perceive factors that influence creativity development: Applying a Social Cognitive Theory perspective. Teaching and Teacher Education, 70, 100-110. https://doi.org/10.1016/j.tate.2017.11.012

Samson, M. K., \& Charles, M. M. (2018). Challenges facing secondary school principals in the implementation of the National Curriculum Statement in Capricorn District of the Limpopo Province. British Journal of Multidisciplinary and Advanced Studies, 2(1), 60-70. http://bjmas.org/journals/british-journal-multidisciplinary-advanced-studies/vol-2-issue-12018/challenges-facing-secondary-school-principals-implementation-national-curriculumstatement-capricorn-district-limpopo-province/

Saundarajan, K., Sharifah Osman, Mohd Fadzil Daud, Mohd Salleh Abu, \& Mohamad Rasidi Pairan. (2020). Learning algebra using augmented reality: A preliminary investigation on the application of Photomath for lower secondary education. International Journal of Emerging Technologies in Learning, 15(16), 123-133.

Shuilleabhain, A. N., \& Seery, A. (2018). Professional development in education enacting curriculum reform through lesson study: A case study of Mathematics teacher learning. Professional Development in Education, 44(2), 222-236. https://doi.org/10.1080/19415257.2017.1280521

Siti Arfah Abd Jalil, Zafarida Kadir, \& Normawar Ali. (2019). Pembangunan alat bahan pembelajaran Lukisan Kejuruteraan 'Orthographic Projection Box.' Journal on Technical and Vocational Education, 4(3), 155-161.

Sorby, S. A., \& Panther, G. C. (2020). Is the key to better PISA math scores improving spatial skills? Mathematics Education Research Journal, 1-21.

Stieff, M. (2019). Improving Learning Outcomes in Secondary Chemistry with VisualizationSupported Inquiry Activities. Journal of Chemical Education, 96(7), 1300-1307. https://doi.org/10.1021/acs.jchemed.9b00205 
Suparmi, Suardiman, S. P., \& Budiningsih, C. A. (2020). The pupil's creativity is inspired by experience through electronic media: Empirical study in Yogyakarta. International Journal of Instruction, 13(2), 637-648.

Tan, O.-S. (Ed.). (2004). Enhancing thinking through problem-based learning approaches: International perspectives. Cengage Learning.

Treeratanaporn, T. (2015). Information technology service management (ITSM) in education. Walailak Journal of Science and Technology, 12(9), 739-747. https://doi.org/10.14456/vol12iss11pp

Umi Fairus Mohd Jamil, \& Fazlinda Ab Halim. (2018). Kaedah mnemonik akronim dalam mata pelajaran Reka Bentuk dan Teknologi di Sekolah Rendah Agama Bersepadu Mersing. Online Journal for TVET Practioners, 3(1).

Wahyu, Y., Suastra, I. W., Sadia, I. W., \& Suarni, N. K. (2020). The effectiveness of mobile augmented reality assisted STEM-based learning on scientific literacy and students' achievement. International Journal of Instruction, 13(3), 343-356.

Wang, T. (2019). Competence for students' future: Curriculum change and policy redesign in China. ECNU Review of Education, 2(2), 234-245. https://doi.org/10.1177/2096531119850905

Wetzel, S., Bertel, S., Montag, M., \& Zander, S. (2020). Spatial task solving on tablets: Analysing mental and physical rotation processes of 12-13-year olds. Educational Technology Research and Development, 68(1), 363-381. https://doi.org/10.1007/s11423-019-09699-8

Widiyatmoko, A. (2018). The effectiveness of simulation in Science learning on conceptual understanding: A literature review. Journal of International Development and Cooperation, 24(1), 35-43.

Wiji, W., \& Mulyani, S. (2018). Student's mental model, misconceptions, troublesome knowledge, and threshold concept on thermochemistry with DToM-POE. Journal of Physics: Conference Series, 1013, 012098.

Wong, K.-T., Mazura@ Mastura Muhammad, \& Norazilawati Abdullah. (2020). Exploring the drivers of intention to use Interactive Whiteboards among Malaysia university students: Does technology self-efficacy matter? International Journal of Emerging Technologies in Learning, 15(1), 163-175.

Yang, H., \& Liu, Y. (2019). Application of knowledge visualization in senior high school Information Technology classroom teaching. 2019 5th International Conference on Social Science and Higher Education (ICSSHE 2019), 336, 22-25.

Yao, J., Sun, H., Tian, Y., \& Gu, H. (2019). Project-Based Learning in Chinese Middle-School Students Is More Effective than the Traditional Teaching Method: An Experimental Study. Science Insights Education Frontiers, 2(2), 115-121. https://doi.org/10.15354/sief.19.ar052

Zamri Sahaat, \& Nurfaradilla Mohamad Nasri. (2020). Cabaran pelaksanaan mata pelajaran Reka Bentuk dan Teknologi sekolah menengah. Jurnal Pendidikan Malaysia, 45(1), 51-59. https://doi.org/10.17576/jpen-2020-45.01si-07 